\title{
Effect of Thymol against Fungi Deteriorating Mural Paintings at Tell Basta Tombs, Lower Egypt
}

\author{
Akmal A. Sakr ${ }^{1,2}$, Mohamed F. Ghaly ${ }^{2}$, Gamal E. Helal ${ }^{2}$, Mahmoud E.F. Abdel Haliem ${ }^{2}$ \\ ${ }^{1}$ Conservation Department, National Museum of Egyptian Civilization (NMEC), Cairo, Egypt \\ ${ }^{2}$ Botany Department, Faculty of Science, Zagazig University, Zagazig, Egypt \\ ${ }^{3}$ Conservation Department, Faculty of Archaeology, Cairo University, Cairo, Egypt
}

*Corresponding Author: Akmal A. Sakr, Conservation Department, National Museum of Egyptian Civilization (NMEC), Cairo, Egypt

\begin{abstract}
Twenty five fungal isolates were collected from mural paintings, air and stone surfaces at Tell Basta tombs and were attributed to Aspergillus versicolor, A. japonicus, A. restrictus, A. terrus, A. fumigatus and A. nidulans, Fusarium oxysporum and Penicillium sp. Moreover, A. japonicus was the, most present in the total fungal samples.

The isolated fungi showed to be involved in fading of azurite blue and red hematite pigments due to the bioaccumulation of copper $(\mathrm{Cu})$ and iron $(\mathrm{Fe})$ ions, respectively, on the fungal cell wall. Fe ions enhanced the biomass, but $\mathrm{Cu}$ ions enhanced melanin production.

Thymol was used with different concentrations $(10,20,30,50,100 \mu \mathrm{g} / \mathrm{ml})$ to inhibit the fungal growth and the concentration $100 \mu \mathrm{g} / \mathrm{ml}$ was the most effective. Isolated fungi varied in their resistance profile to the tested thymol concentrations since Penicillium sp. was the most resistant, but A. japonicus was the most sensitive.

Thymol caused yellowing of the treated surfaces, so fumigation method was recommended. Furthermore, fumigation reduced the microbial colonization of paintings significantly. On the other hand, thymol caused color change neither for the tested pigments nor for the appearance of stone surfaces.
\end{abstract}

Keywords: Biodegradation, Fumigation, Mural Paintings, Tell Basta, Thymol, Discoloration, Upper Egypt

\section{INTRODUCTION}

Mural paintings within Tell Basta (Bubastis) tombs are often subjected to fungal deterioration, since fungi play an important role in biodeterioration of mural paintings. Fungi cause chromatic alteration through forming irreversible stains resulted in secreting extracellular in nature of melanin and carotenoid pigments (Sterflinger et al. 1999), even after the fungus is dead, the pigmented cell walls remain on the surface of the paintings and stone surfaces and these strains are resistant to chemical and enzymatic degradation (Kiyuna et al. 2011). The structural damage is caused by fungal metabolites of acids that are extremely erosive (Sterflinger, 2010) and these acids cause chromatic alterations of paintings (Ravikumar et al. 2012). Furthermore, produced enzymes could decompose the binding media of the mural paintings, such as egg yolk, animal glue and arabic gum into free amino acids and mono sugars that could be used as carbon source for fungal growth and colonization (Milanesi et al. 2006).

Fungal deterioration of mural paintings in ancient Egyptian tombs was put onto the evidence, since mural paintings in the tomb of the King Tutankhamen ( $18^{\text {th }}$ Dynasty) were stained with brown-black spots, that resulted in the growth and colonization of Aspergillus penicilloides (Arai 2004; Vasanthakumar et al. 2013). Furthermore, Cladosporium sp. disfigured mural paintings in the tomb of the King Amenophis III (1 ${ }^{\text {th }}$ Dynasty) by forming black stains (Arai 2004). Also Penicillium, Aspergillus, Alternaria and Cladosporium hebarum formed black stains on mural paintings within the tomb of Petosiris that dated back to the Ptolemaic period (El-Deeb et al. 2000). Moreover, Cladosporium showed to be involved in disfiguration of stone surfaces in the tomb of the Queen Nefertari (18 $8^{\text {th }}$ Dynasty) with black spots (Preusser 1987). In addition, Cladosporium cladosporoides, Alternaria alternata and Aspergillus niger caused discoloration of mural paintings in the Temple of Abydos (19 ${ }^{\text {th }}$ Dynasty) with dark brown stains (El Sharouny et al. 2000b). 
Due to the aesthetical and structural damages that fungi are causing to mural paintings and stone surfaces, their growth should be controlled.

Biocontrol appears to be a reliable alternative to chemical fungicides, because the applied fungicides are highly toxic and impose environmental hazards for both the treated objected and conservators, so the new trends used environmentally safe methods of plant extracts and essential oils such as thyme and its derivatives to control fungi colonizing cultural heritage objects. These substances have high potent antimicrobial activity and low toxicity for human and environment (Unger et al. 2001; Haines and Kohler 1986).

Thymol is the most common constituent of essential oils derived from Thymus and Origanum plants, and confers antimicrobial properties to these oils (Liang et al. 2007), that may explain its plant origin as a chemical defense mechanism against phytopathogenic microorganisms (Numpaque et al., 2011). This antimicrobial activity is attributed to the phenolic compounds that have a wide spectrum of antimicrobial activity against fungi and bacteria ( $\mathrm{Hu}$ et al. 2008; Rota et al. 2008; Soumya et al. 2011).

Because of its efficacy, it is often used as preservative agent for organic cultural heritage objects such as library and other archival materials made of paper (Veilkova et al. 2011), leather and parchment (Sirvaityte et al. 2012).

Because thymol is only fungistatic, and no fungicidal effect was recorded, so it could be used in combination with other substances such as antibiotics (Ahmad et al. 2010) and mercuric chloride (Sadurska and Kowalik, 1968) due to the synergistic effect of thymol and antibiotics or mercuric chloride.

To date, several problems have been encountered in application of thymol with diffusion method for inhibiting fungi colonizing cultural heritage objects, such as turning yellow at exposure to sun light or UV radiation for a long period. This yellowing phenomenon was attributed to the oxidation of phenol groups and hydroxyl group that transformed into carbonyl group and thymoquinone or dithymoquinone with yellow color strongly absorbed in FT/IR spectra (Daniels and Boyd 1986). For this reason, thymol was used exclusively since 1983 as preservative agent for archives in the United Kingdom in fumigation within closed boxes containing thymol, called fumigation chambers (Craig 1986).

The fumigation method is more effective than the contact one in controlling biodeteriorated cultural heritage objects (Daniels and Boyd 1986; Collis, 1970). This may be attributed to the matter of fact that fumigation provides a continual presence of thymol vapors within the exhibition cases that remain for weeks or even months after fumigation, thus reducing the numbers of viable spores able to recolonize these objects in the future. Furthermore, fumigation leaves no residues on organic cultural heritage objects such as parchment or paper (Haines and Kohler1986; Strassberg1978).

Efficacy of thymol fumigation should depend on the application conditions, such as type of fungi, concentration of thymol and relative humidity of the surrounding environment since it was reported that thymol fumigation is more effective if the objects are dried or in an environment with low humidity (Unger et al. 2001).

This mode of action of thymol vapors on the treated fungi may be attributed to disruption of membrane integrity in fungi (Liang et al. 2007) and this structural distortion would cause deterioration of the membrane and would increase membrane permeability (Altiok et al. 2010).

Finally, thymol fumigation could be used as preventive agent after the treatment of deteriorated cultural heritage using gamma irradiation due to short term effect of gamma irradiation (Abdel Haliem et al., 2013a)

The objective of this work was to isolate and characterize fungi colonizing mural paintings in the tombs at Tell Basta area, and to examine the resistance profiles of isolated fungi to different concentrations of thymol. Finally, the effect of thymol on different pigments is described herein.

\section{Materials AND MethodS}

\subsection{Sampling Location}

Twenty five samples of fungi were collected from paintings, stone surface, and air within five tombs (Ankh h3 f, Ihy, Ist, Ankh m b3st and unknown tomb) at Tell Basta (Bubastis in the Greec Roman 
Period), East of Delta, Sharkyia Governorate that were discovered in 1980s-1990s (Figure.1), sampling was through June-July 2010.

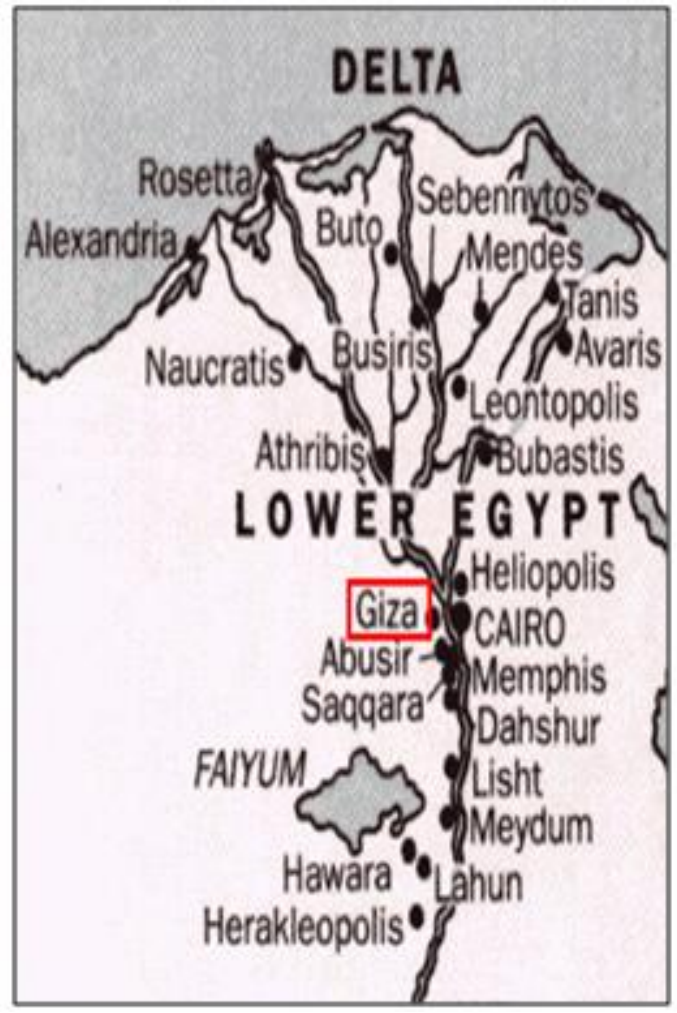

Figure1a.The location of sampling site

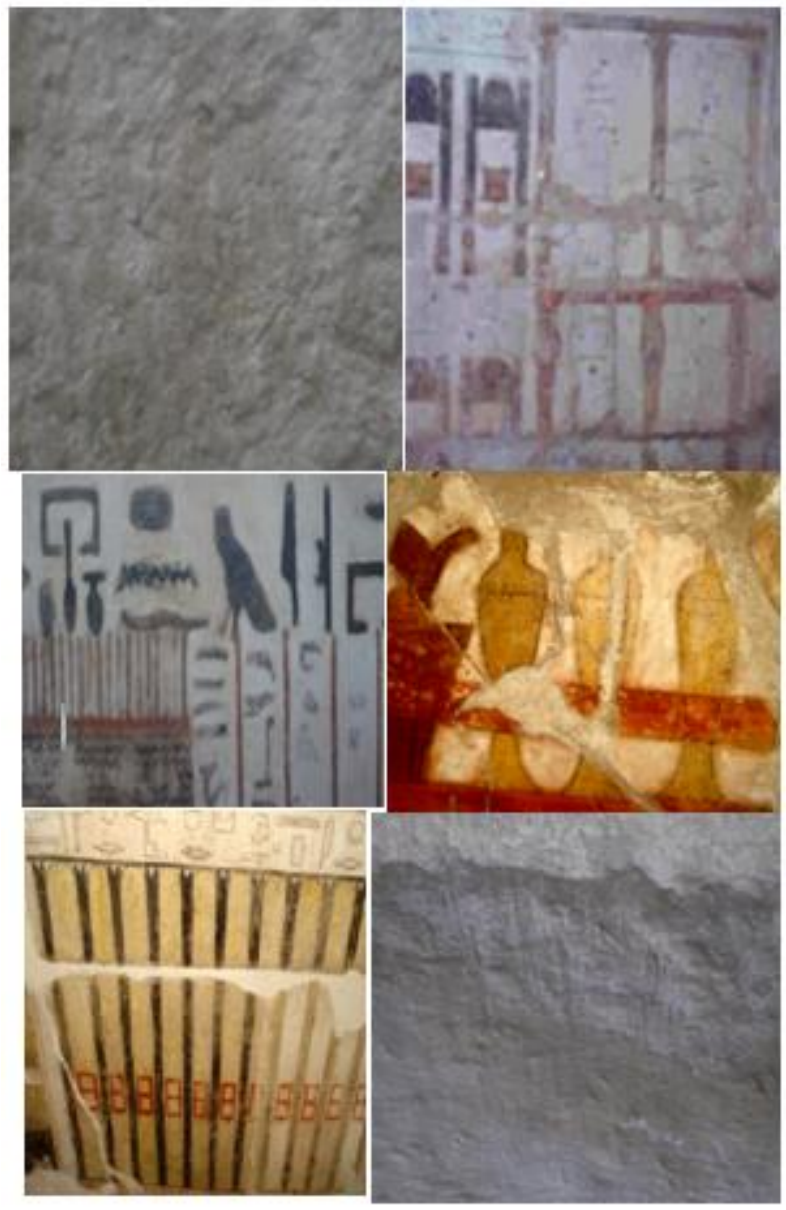

Figure1b. Location samples from Tell Basta tombs 


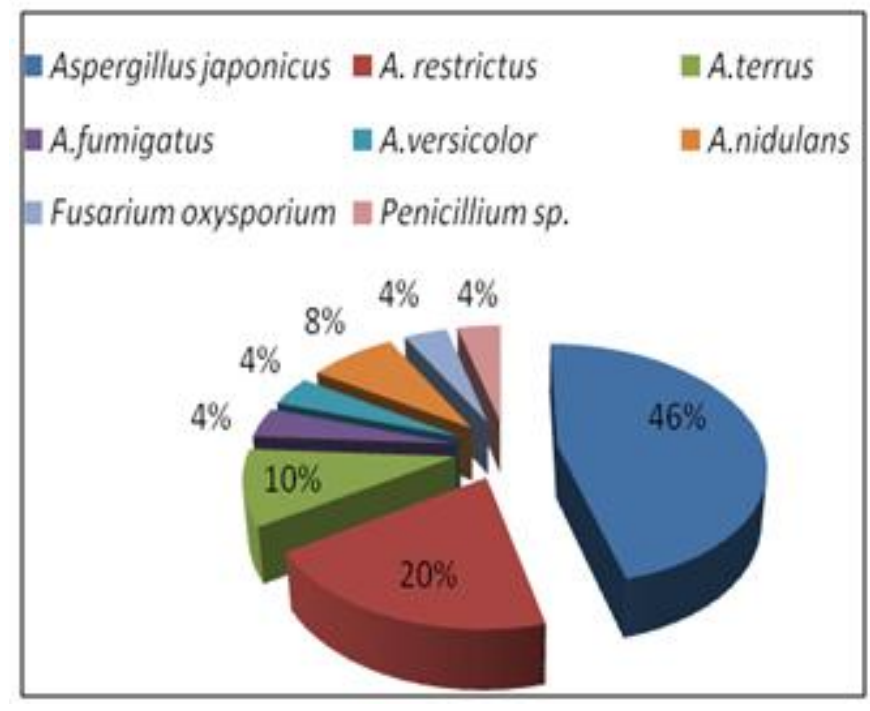

Figure2. Percentage of fungal isolates

After sampling, to extract microorganisms, sterile cotton swabs were aseptically suspended in $1 \mathrm{ml}$ saline $(0.9 \% \mathrm{NaCl}$ ), amended with $0.1 \mathrm{ml}$ Tween 80) (Descheemaeker and Swings, 1995) and vortexed for $10 \mathrm{~min}$ using a programmable rotator-mixer (model Mutli RS-60). Thereafter an aliquot of $0.1 \mathrm{ml}$ was cultured onto Dox-Czapek agar medium plates (g/l) (sucrose $30, \mathrm{~K}_{2} \mathrm{HPO}_{4} 1, \mathrm{NaNO}_{3} 3$, $\mathrm{MgSO}_{4} .7 \mathrm{H}_{2} \mathrm{O} 0.5, \mathrm{KCl} 0.5, \mathrm{FeSO}_{4} .5 \mathrm{H}_{2} \mathrm{O} 0.01$, agar 20/L distilled water) supplemented with antibacterial chloramphenicol $(0.05 \mathrm{~g} / \mathrm{l})$ to inhibit the rapid growth of bacteria, plates were incubated for 5 days at $25^{\circ} \mathrm{C}$, where micro fungi appeared (Šimonovicova et al. 2004). Air samples were collected from the air within the investigated tombs according to Abdulla et al. (2008) using automated air sampler (Microbio Air Sampler MB2, Parrett LTD, UK) where fixed volume of air samples were collected over $1 \mathrm{~min}$, directly onto Dox-Czapek agar medium plates, incubated for 5 days at $25^{\circ} \mathrm{C}$.

\subsection{Isolation and Identification of Fungi}

Micro fungi were identified microscopically and morphologically according to the identification keys of Booth (1977); Raper and Fennell (1977); Raper et al. (1968), and this classification was confirmed by analysis of $18 \mathrm{~S}$ rDNA sequence of these isolates.

\subsection{Effect of Copper and Iron Based Pigments on the Isolated Fungi}

To investigate the effect of iron based and copper based pigments on the growth of the isolated fungi, fungal isolates were cultured on broth Dox-Czapek medium, since $250 \mathrm{ml}$ Erlenmeyer flasks were used, each one contained $20 \mathrm{ml}$, supplemented with $0.01 \% \mathrm{CuSO}_{4} .7 \mathrm{H} 2 \mathrm{O}$ and anhydrous ferrous sulphate $\left(\mathrm{FeSO}_{4}\right)$ respectively, incubated for 7 days at $28^{\circ} \mathrm{C}$. $\mathrm{Cu}$ and $\mathrm{Fe}$ ratio in the biomass were estimated according to Humar et al. (2004). The fungal biomass was washed with distilled water and burnt in an oven at $150^{\circ} \mathrm{C}$ for $12 \mathrm{~h}$ to get rid of organic matters. $1 \mathrm{~g}$ of burnt biomass was dissolved in $2 \mathrm{ml} \mathrm{HOCl}+2 \mathrm{ml} \mathrm{HNO}_{3}+20 \mathrm{ml}$ distilled water and left over night. Ratio of $\mathrm{Cu}$ and $\mathrm{Fe}$ ions in both treated and control samples cultured onto Dox plates free $\mathrm{Cu}$ and $\mathrm{Fe}$ ions were estimated in $\mathrm{ppm} / \mathrm{g}$ using atomic absorption (Unica 969 Atomic Absorption Spectroscopy, Veternary Medicine, Zagazig University).

\subsection{Acidolytic Activity of Isolated Fungi}

To examine the acidolytic activity of isolated fungi. Erlenmeyer (250-mL) flasks were used. Each flask contained $50 \mathrm{~mL}$ of the broth Dox-Czapek medium, fungal isolates were inoculated and incubated at $28 \mathrm{C}$ for $72 \mathrm{~h}$. After incubation period, $0.1 \mathrm{ml}$ of medium was injected in HPLC National Research Centre, Dokky, Giza. Standard organic acids were used.

\subsection{The Chemical Composition of Thymol}

To have better understanding of mortality mechanism of thymol on isolated fungi, its chemical composition must be investigated, this was carried out using: 


\subsubsection{Mass Spectra}

Thymol sample was identified using Mass spectra (JEOL, JMS-AX500 Mass spectra, National Research Centre, Dokky, Cairo).

\subsubsection{H NMR Spectra}

Thymol was analyzed with NMR (JEOL-ECA 500 Mega Heritz, National Research Centre, Dokky, Cairo).

\subsubsection{FT/IR Spectra}

The chemical structure of thymol was analyzed by FT/IR spectroscopy (JASCo. FT-IR 6100, National Research Centre, Dokky, Cairo) according to Derrick et al. (1999).

\subsection{Effect of Thymol on the Isolated Fungi}

Thymol, mainly in its crystalline form was provided by Sigma Chemical Co., Cairo. Thymol has poor solubility in water, so it was used in dimethyl sulphoxide (DMSO) with different concentrations (10, $20,30,50,100 \mu \mathrm{g} / \mathrm{ml})$. Filter paper discs saturated with the solution were used according to Sakr et al. (2012).

On the other hand, the fumigation cabinet containing thymol as a fumigant was used according to Rakotonirainy and Lavedrine (2005), where models of colonized objects were placed on a small mesh of polypropylene within a glass jar and the colonized surface was in the face of thymol solution. Thymol solution was placed in a Petri dish $(\mathrm{d} 7 \mathrm{~cm})$ and a container with $250 \mathrm{ml}$ with salt solution of ammonium nitrate and magnesium sulphate within the fumigation chamber to regulate the relative humidity (RH) level at $50 \%$ and $80 \%$ respectively. After exposure of the colonized models to thymol vapors (3-14 days), swabs were taken from different zones of these models and cultured onto fresh Dox-Czapek plates to detect viability of fungal spores. Survival of spores was normalized against control samples of non fumigated fungi.

To study the mode of action of thymol on the isolated fungi, control and treated samples of $A$. japonicus, the most present fungus, were examined using scanning electron microscope (JOLE. SEM 6300, National Research Centre, Cairo) according to Milanesi et al., (2006).

\subsection{Schematic of Fumigation Chamber}

The traditional fumigation chamber cabinet was modified whereas this chamber was supplemented with data logger to monitor relative humidity and temperature and with small fan to make air circulation so thymol vapors contact with fungal spores for longer period.

\subsection{Effect of UV and Sun Light on Thymol}

To explain the yellowing phenomenon of thymol, a solution of thymol in dimethyl sulfoxide (DMSO) was exposed to both sun light and UV lamps (TUV 40w) for seven days. Thymol traces were analyzed by FT/IR spectroscopy (JASCo. FT/IR 6100, National Research Centre, Dokky, Cairo), IR patterns were compared against the control samples of thymol.

\subsection{Effect of Thymol on Different Pigments}

To investigate the effect of thymol on pigments used in mural paintings, different pigments such as hematite, limonite, azurite, malachite, carbon black, red lead, cinnabar and lead carbonate were tested using different concentrations of thymol. The potential changes in the composition of pigments due to effect of thymol were determined by FT/IR spectroscopy (JASCo. FT/IR 6100, National Research Centre, Dokky, Cairo).

\section{RESUlts}

\subsection{Identification of Fungal Strains}

The identification based on culture-dependent techniques showed that twenty five fungal strains isolated from Tell Basta tombs (from air, paintings and stone surfaces) were belonging to Aspergillus japonicus (46\%), A. restrictus (20\%), A. terrus (10\%), A. fumigates (4\%), A. versicolor (4\%), A. 
nidulans (8\%), Fusarium oxysporum (4\%) and Penicillium sp.(4\%) (Figure.3a). On the other hand, it was found that $30 \%$ of fungal isolates were from air, $27 \%$ from limestone surfaces and $43 \%$ from paintings, indicating selectivity of fungi in biodeterioration (Table 1).

Biochemical identification was confirmed using molecular methods, and $18 \mathrm{~S}$ rDNA sequencing pointed out that isolated fungi are belonging to Aspergilli, Penicilli and Fusarium genera and their accession numbers are illustrated in Table 2.

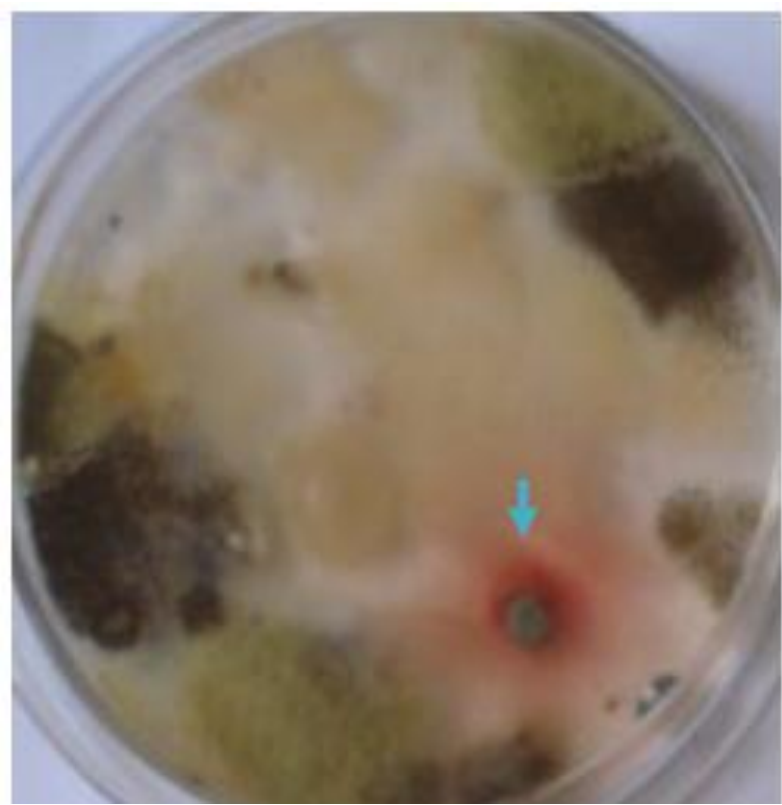

Figure3. Producing pinky pigment by F. oxysporum

Table1. Location of fungal isolates

\begin{tabular}{|c|c|}
\hline Fungal isolates & Location \\
\hline A. versicolor (Vuill.) & Limestone, tomb of Ankh h3 f \\
\hline A. japonicus Saito & Air, tomb of Ankh h3 f \\
\hline Fusariumoxysporum Schlech & Limestone unknown tomb \\
\hline A. restrictus Smith & Limestone unknown tomb \\
\hline A. japonicus Saito & Limestone, tomb of Ankh m b3st \\
\hline A. restrictus Smith & Air, tomb of Ankh m b3st \\
\hline A. restrictus Smith & Air, tomb of Ankh m b3st \\
\hline A. terreus Thom & Air, tomb of Ankh h3 f \\
\hline A. restrictus Smith & Air, tomb of Ankh h3 f \\
\hline A. japonicus Saito & Air, tomb of Ihy \\
\hline A. japonicus Saito & Black color, tomb of Ihy \\
\hline A. terreus Thom & Air, tomb of Ist \\
\hline A. japonicus Saito & Limestone, tomb of Ist \\
\hline A. japonicas & Red color, tomb of Ankh m b3st \\
\hline A. nidulans (Eidam) Wint & Red color, tomb Ankh m b3st \\
\hline A. japonicus Saito & Yellow color, tomb of Ankh m b3st \\
\hline A.japonicus Saito & Limestone, tomb of Ankh h3 f \\
\hline A.fumigatus Fresenius & Black color, tomb of Ankh h3 f \\
\hline A.terreus Thom & Red color, tomb of Ihy \\
\hline A.japonicus Saito & Blue color, tomb of Ihy \\
\hline Penicillium sp. & 39GwAQ7PeH7fJTFa4DXguurfn7GULq2pT \\
\hline Penicillium sp. & Black color, tomb of Ihy \\
\hline A. versicolor (Vuill.) & Red color, tomb of Ankh m b3st \\
\hline A. japonicus Saito & Air, tomb of Ihy \\
\hline
\end{tabular}


Table2. Phylogenetic affiliation of inoculated strains (homology of $18 S$ rDNA and similarity in comparison with NCBI data)

\begin{tabular}{|c|c|c|c|}
\hline Sampling location & Affiliation & $\begin{array}{l}\text { Similarity to NCBI } 16 \mathrm{~S} \\
\text { rDNA }\end{array}$ & $\begin{array}{l}\text { NCBI accession number } \\
\text { sequence }\end{array}$ \\
\hline $\begin{array}{l}\text { Azurite blue, tomb of } \\
\text { Ihi, Tell Basta }\end{array}$ & A. japonicus Saito $99 \%$ & BankIt & \\
\hline $\begin{array}{l}\text { Yellow color,Southern } \\
\text { Wall of the tomb of } \\
\text { Ankh h3 f Tell Basta }\end{array}$ & $99 \%$ & BankIt1507642 & JQ625332 \\
\hline $\begin{array}{l}\text { Blue color, ceiling of } \\
\text { the tomb of Oserkon } \\
\text { II, Tanis }\end{array}$ & $99 \%$ & BankIt1507650 & JQ625337 \\
\hline $\begin{array}{l}\text { Black color, tomb of } \\
\text { Ankh h. f.,Tell Basta }\end{array}$ & $100 \%$ & BankIt1507649 & JQ625336 \\
\hline $\begin{array}{l}\text { Red color, tomb of } \\
\text { Ankh m b3st,Tell } \\
\text { Basta }\end{array}$ & $99 \%$ & BankIt1507648 & JQ625335 \\
\hline $\begin{array}{l}\text { Limestone, tomb of } \\
\text { Oserkon II, Tanis }\end{array}$ & $98 \%$ & BankIt1507647 & JQ625334 \\
\hline $\begin{array}{l}\text { North wall, tomb of } \\
\text { Ist, } \\
\text { Tell Basta }\end{array}$ & $98 \%$ & BankIt1507149 & JQ625330 \\
\hline $\begin{array}{l}\text { Yellow color,southern } \\
\text { wall of the tomb of } \\
\text { Ankh h3 Tell Basta }\end{array}$ & $99 \%$ & BankIt1507645 & JQ625333 \\
\hline
\end{tabular}

${ }^{a}$ Alternative affiliation is $S$. pyridomyceticus.

${ }^{b}$ Alternative affiliation is $S$. flavovirens.

\subsection{Acidolytic Activity of Isolated Fungi}

$\mathrm{pH}$ values of broth medium were deceased, and gradual decreasing was observed with increasing of incubation period, and HPLC data indicated that isolated fungi produce a variety of organic acids and oxalic acid was the most present (unpublished data).

\subsection{Fungal Biopigment Productin}

The fungal isolate ( $F$. oxysporum) isolated from red stains on painting and stone surface in produced a pinky pigment was extracellular in nature (Fig. 3).

\subsection{Effects of $\mathrm{Cu}$ and $\mathrm{Fe}$ on the Fungal Growth}

Current results indicated that $\mathrm{FeSO}_{4} 2 . \mathrm{H}_{2} \mathrm{O}$ enhanced biomass of A. japonicus Saito that was isolated from yellow paintings, tomb of Ankh $\mathrm{m}$ b3st. On the other hand, the atomic absorption data indicated that biomass of $A$. japonicus cultured on $\mathrm{FeSO}_{4} 2 \cdot \mathrm{H}_{2} \mathrm{O}$ bioaccumulated $\mathrm{Fe}$ ions on fungal cell wall at $200 \mathrm{ppm} / \mathrm{g}$ of biomass. On the contrary, copper sulphate $\mathrm{CuSO}_{4} \cdot 7 \mathrm{H}_{2} \mathrm{O}$ reduced the growth of all fungal isolates in comparison with control samples and enhanced melanin production. Moreover, the atomic absorption data pointed that $A$. japonicus bioaccumulated $\mathrm{Cu}$ ions on the fungal cell walls at $120 \mathrm{ppm} / \mathrm{g}$ of biomass.

\subsection{Chemical Composition of Thymol and its Color Change at Exposure to UV Light}

From the spectral analysis, Mass spectra, ${ }^{1} \mathrm{H}$ NMR spectra and FT/IR, we could conclude that thymol is composed of $\beta$-cymene (molecular weight is 135) and carvacrol (Fig.4). Moreover, ${ }^{1} \mathrm{H}$ NMR spectra showed signals at $\delta 2.2\left(\mathrm{~S}, 3 \mathrm{H}, \mathrm{CH}_{3}\right), 3.5$ (sept. $\left.{ }^{1} \mathrm{H}, \mathrm{CH}\right), 6.26-8.0(\mathrm{~m}, 3 \mathrm{H}$, Aromatic), and 9.0 $\left(\mathrm{S}\right.$, broad, $\left.{ }^{1} \mathrm{H}, \mathrm{OH}\right)$ (Figure.5). Finally, FT/IR pattern showed the presence of phenol groups that exhibited intense bands at $3423 \mathrm{~cm}^{-}{ }^{1}$ characterizing phenol groups (Figure.6a).

So from the spectral analysis we could conclude that the chemical composition of thymol is 2 isopropyl-5-methylphenol and its molecular formula is $\mathrm{C}_{10} \mathrm{H}_{14} \mathrm{O}$ (Fig. 6d) and thymol is not in pure form.

After the exposure of thymol to sun rays and UV, it was possible to observe the yellowing of thymol. IR spectra of thymol samples exposed to and UV sun light indicated presence of $\mathrm{CH}$ aromatic at 3030 $\mathrm{cm}^{-1}$,carbonyl group $(\mathrm{C}=\mathrm{O})$, the main bands were at $1723 \mathrm{~cm}^{-1}$, and the fingerprint band of quinon group (ON-O-R) showed at $695 \mathrm{~cm}^{-1}$ (Figure.6 b-c). 


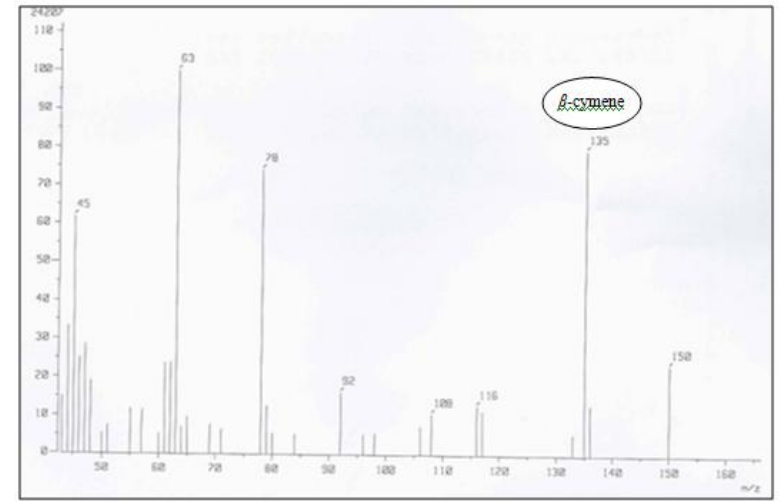

Figure4. Mass spectra of thymol

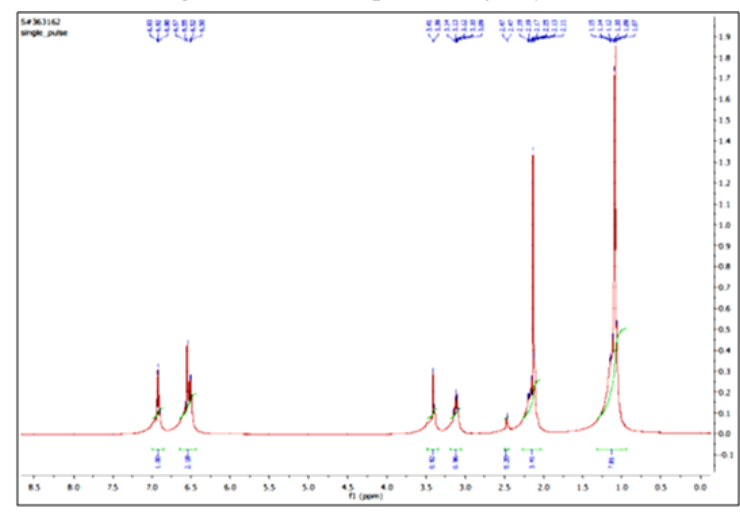

Figure5. ${ }^{l}$ HNM spectra of thymol
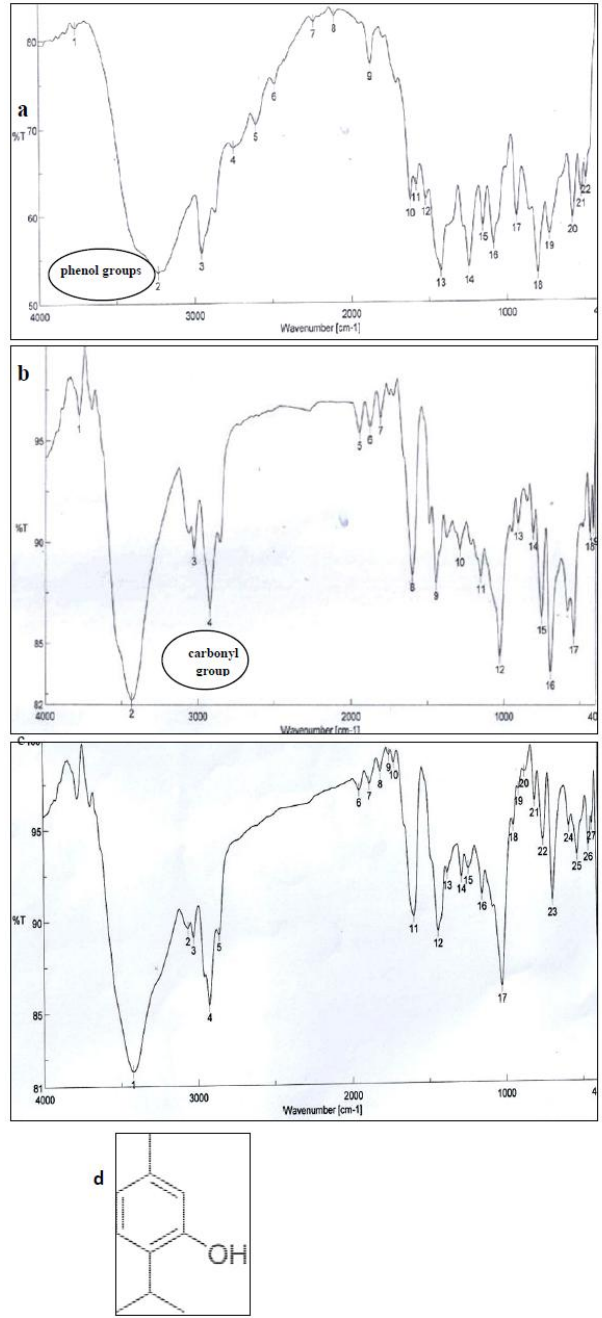

Figure6. FT/IR spectra of thymol (a) control (b-c) exposed to UV light (d) molecular structure of thymol 


\subsection{Effect of Thymol on the Growth of Fungi}

Results showed that the effect of thymol on the isolated fungi varied according to its concentration and evidenced that the concentration $10 \mu \mathrm{g} / \mathrm{ml}$ was not effective, but the concentration $100 \mu \mathrm{g} / \mathrm{ml}$ inhibited the growth of the isolated fungi for five days (Table 2), but after ten days, fungi recolonized again over the filter paper discs (Figure.7).

The isolated fungi varied in their resistance profile to tested concentrations of thymol, whereas Penicillium sp. was the most resistant, but A. japonicus was the most sensitive (Figure.8a).

The other determinant of efficacy of thymol on the isolated fungi was relative humidity (RH), whereas our results pointed out that thymol was more effective in low $\mathrm{RH}(30 \%)$ and less effective in higher RH (70\%) (Figure 8b).

Moreover, TEM micrographs pointed out that the treatment of A. japonicas, the most present fungus, with different concentrations of thymol delayed spore formation and enhanced deformation of fungal spores (Fig.9).

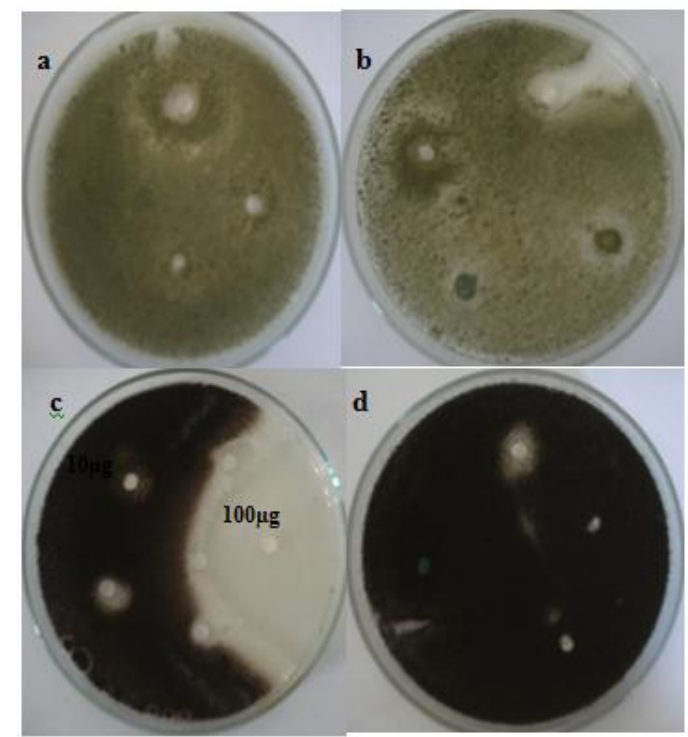

Figure7. Effect of different concentrations of thymol on (a): penicillum sp. after five days of treatment. (b): after ten days of treatment. (c): A. japonicus after five days of treatment. (d): after ten days of treatment.

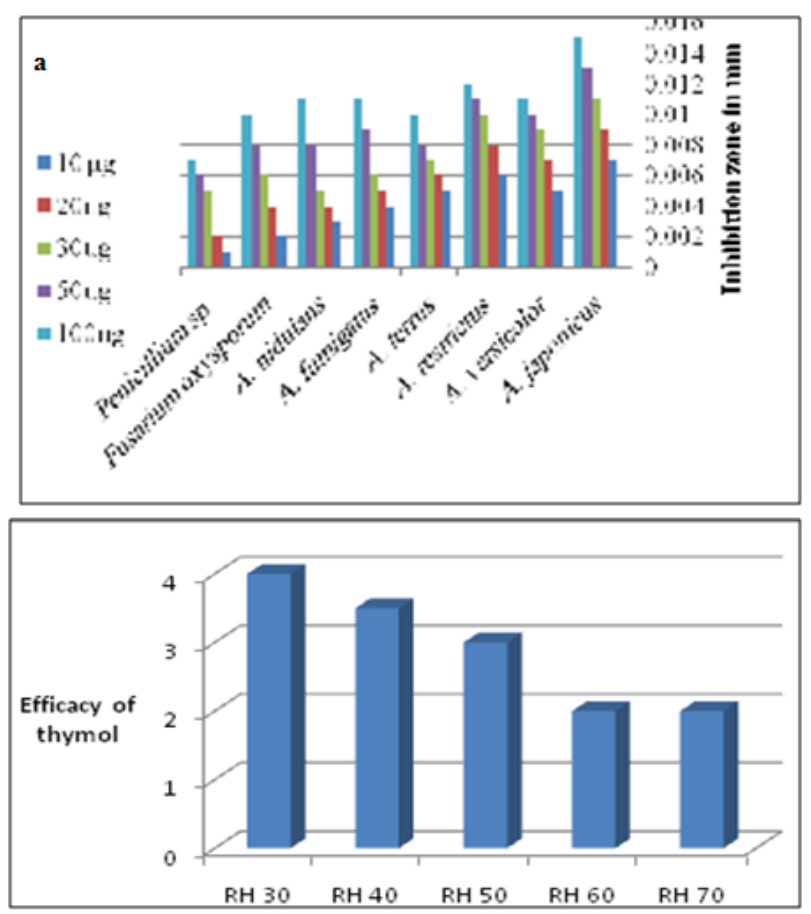

Figure8(a). Effect of different concentrations of thymol on the fungal isolates. (b) the relationship between efficacy of thymol and relative humidity 

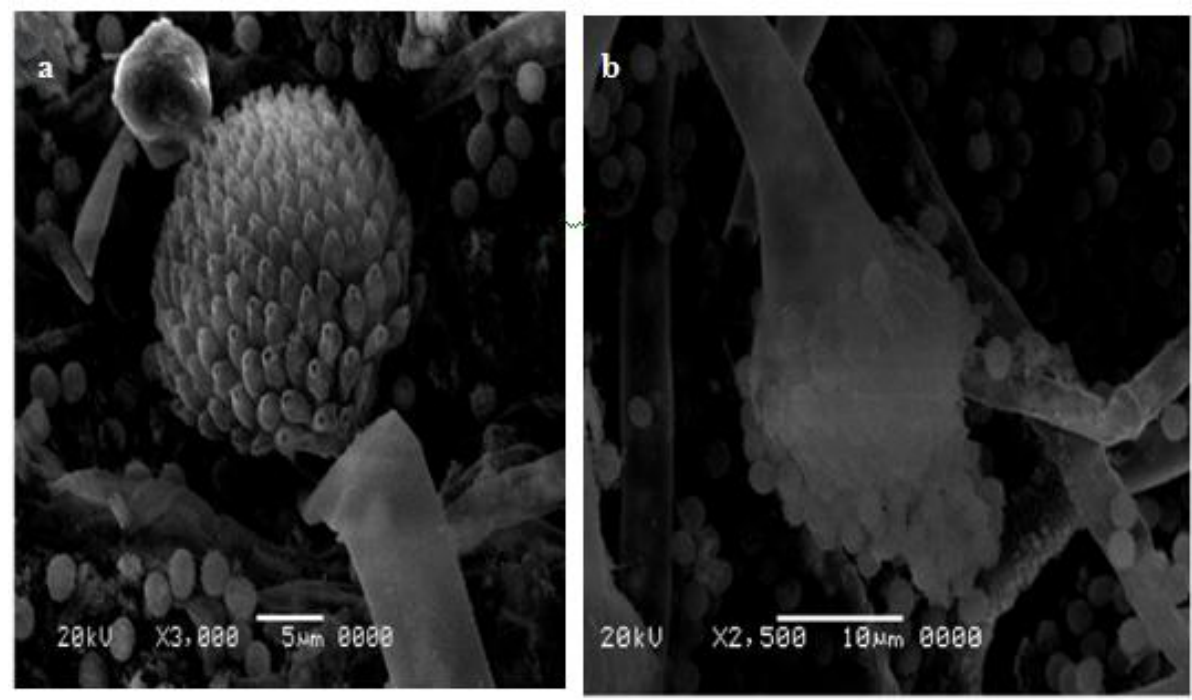

Figure9. SEM micrograph illustrates spore deformation of A. japonicus by thymol $100 \mu \mathrm{g}$ (a) control, (b) treated isolate

\subsection{Schematic of Fumigation Chamber}

To reduce conservation interventions with direct contact on archeological surfaces, a modified thymol fumigation chamber was used, a modified form of glass test chamber. This chamber was of plexi glass provided with fan to make air circulation within the fumigation chamber and data logger to observe relative humidity and temperature respectively, and humidifier of magnesium sulfate was used to adjust relative humidity to the required level (Figure.10). Our results indicated that using thymol in fumigation within the fumigation chamber prevented re-growth of fungi for a long period of time, more than five months at $20 \mathrm{C}$ and $\mathrm{RH} 45 \%$. The amount of thymol required for fumigation ranged from $40-50 \mathrm{~g} / \mathrm{m}^{3}$ and cfu of fungal cells reduced significantly (Table 3 ).

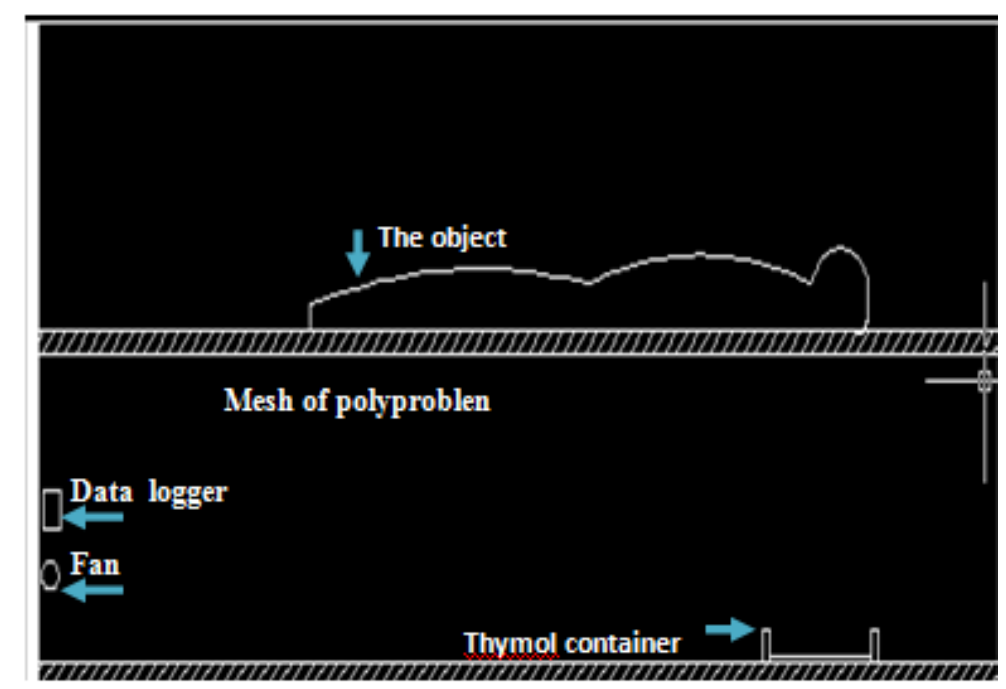

Figure10. Systematic of fumigation chamber

Table3. Effect of different concentrations of thymol on fungal species

\begin{tabular}{|l|l|l|l|l|l|}
\hline \multicolumn{5}{|c|}{ Fungal isolates Inhibition zone $(\mathrm{mm})$ of different Concentration of thymol $\mu \mathrm{g} / \mathrm{ml}$} \\
\hline Fungal isolates & 10 & 20 & 30 & 50 & 100 \\
\hline A. fumigatus & - & 5 & 7 & 10 & 14 \\
\hline A. japonicas & - & 10 & 12 & 19 & 25 \\
\hline A.nidulans & - & 3 & 6 & 8 & 12 \\
\hline A. restrictus & - & 7 & 9 & 14 & 18 \\
\hline A. terrus & - & 6 & 8 & 12 & 17 \\
\hline A. versicolor & - & 7 & 10 & 14 & 20 \\
\hline F.oxysporum & - & 2 & 4 & 6 & 11 \\
\hline Penicillium sp. & - & 1 & 3 & 5 & 10 \\
\hline
\end{tabular}


Table4. Reduction of fungal colonies after fumigation

\begin{tabular}{|l|l|l|}
\hline Fungal isolate & cfu of viable spores \\
\hline & Before & After 10 days \\
\hline A. fumigates & $8 \times 10^{3}$ & $3 \times 10^{1}$ \\
\hline A. japonicus & $6 \times 10^{2}$ & $1 \times 10^{1}$ \\
\hline A.nidulans & $3 \times 10^{2}$ & $1 \times 10^{1}$ \\
\hline A. restrictus & $7 \times 10^{3}$ & $2 \times 10^{1}$ \\
\hline A. terrus & $5 \times 10^{2}$ & $1 \times 10^{1}$ \\
\hline A. versicolor & $1 \times 10^{3}$ & $1 \times 10^{1}$ \\
\hline F.oxysporum & $4 \times 10^{2}$ & $1 \times 10^{1}$ \\
\hline Penicillum sp. & $2 \times 10^{3}$ & $7 \times 10^{1}$ \\
\hline
\end{tabular}

\subsection{Effect of Thymol Concentrations on Different Pigments}

Finally, FT/IR spectra pointed out that thymol used in fumigation at the concentrations tested in this study had no effect on the investigated pigments such as hematite, limonite, malachite, azurite and black carbon (unpublished data)

\section{DISCUSSION}

Our results are consistent with the previous studies showing that Aspergillus group reported their presence with six species; A. versicolor, A. japonicus, A. restrictus, A. terreus, A. nidulans, A. fumigatus, Fusarium oxysporum and Penicillium sp. were the most present species in the deteriorated mural paintings (Sterflinger, 2010; Garg et al. 1995; Guglielminetti et al. 1994) and were biodeteriorative agents for various monuments (Biswas et al. 2013). On the other hand, it was well documented that Aspergillus was the most present deteriorating agent for mural paintings within the temple of Abydos, Upper Egypt, and strongly associated with seasonal environmental fluctuations (El Sharonuny et al. 2000a).

Our finding pointed out that there is a difference between fungi isolated from air, limestone surfaces and paintings that indicated the selectivity of fungi involved in deterioration of paintings and stone surfaces within the investigated tombs (Karbowska-Berent et al. 2011).

Current results showed that $F$. oxysporum, produced a pinky pigment on Czapek-Dox plates that causes disfiguration and aesthetic damage of colonized mural paintings and stone surfaces with irreversible stains; in particular these biogenic pigments were extracellular in nature and mostly are resistant to chemical and enzymatic degradation (Ravikumar et al. 2012; Szezpanowska and Lovett 1992). Involvement of fungi in disfiguration of paintings and stone surfaces was put onto the evidence, since the black, green and red stains on wall paintings from ancient tombs in Japan were attributed to the fungal colonization (Garg et al. 1995).

In this study, it was observed that A. japonicus (46\%) was the most isolated fungus because it is a thermophilic fungus and collecting of samples was carried out in the summer months (JuneSeptember) characterized with high temperature more than $50{ }^{\circ} \mathrm{C}$ (da Silva et al. 2012).

Current results indicated decreasing of $\mathrm{pH}$ values with increasing of incubation period, and HPLC data showed that isolated fungi are acid producers and the most produced acids are oxalic, citric and glucconic acids, that cause irreparable chromatic alteration of colonized paintings (Biswas et al. 2013; Ravikumar et al. 2012).

Current results indicated that $\mathrm{FeSO}_{4} 2 \mathrm{H}_{2} \mathrm{O}$ enhanced biomass of A. japonicus Saito isolated from yellow color paintings with limonite from the tomb of Ankh $\mathrm{m} \mathrm{b} 3 \mathrm{st}$. On the other hand, atomic absorption data indicated that the biomass of A. japonicus cultured on $\mathrm{FeSO}_{4} 2 \cdot \mathrm{H}_{2} \mathrm{O}$ bioaccumulated Fe ions on fungal cell walls. This may be explained by the matter of fact the most microorganisms need iron for enzyme function because it is considered the key component of cytochromes and electron carrying proteins, which play a major role in the cellular respiration in subsurface environments (Abdel-Haliem et al., 2013b; Kalinowski et al. 2000).

Furthermore, data obtained from the atomic absorption analyses pointed out that A. japonicus bioaccumulated $\mathrm{Cu}$ ions on the fungal cell walls at $120 \mathrm{ppm} / \mathrm{g}$ of biomass. These results were confirmed those of Milanisi et al. (2006). Also, it was demonstrated that A. juponicus produce citric acid and oxalic acid. (Domsch et al., 1980). 
Moreover,, our finding pointed out that copper sulphate $\mathrm{CuSO}_{4} \cdot 7 \mathrm{H}_{2} \mathrm{O}$ reduced the growth of all isolated fungi and enhanced melanin pigment, that may be attributed to the matter of fact the production of melanin is a defense mechanism against adverse environmental conditions such as heavy metals, hyper salinity, and irradiation whereas melanin acts as a shield preventing access of these heavy metals into microbial cell (Abdel-Haliem et al., 2013b).

Also, it was observed that fungal isolates from blue color was little (1 isolate), that may attributed to the matter of fact that fungi are less resistant to copper based pigments such as azurite blue (CaeserTonthat et al. 1995), the blue pigment detected in the investigated mural paintings at Tell Basta (Abdel-Haliem et al., 2013b).

With regard to the chemical composition of thymol, Mass spectra data indicated that thymol is not a pure form, but it is a mixture of thymol, $\beta$-cymene and carvacrol. In supporting these results, GarcaRisco et al. (2011) and Sirvaityte et al. (2012) reported that thyme oil, the major source of thymol, is composed mainly of thymol (38\%), $\beta$-cymene (8.64\%) and carvacrol $(10.11 \%)$ in addition to terpenoids such as menthol, camphor and phytoln and the ratio of these components varied according to plant source where this oil was extracted.

On the other hand, ${ }^{1} \mathrm{H}$ NMR spectra revealed that thymol has simple organic structure is 2-isopropyl5-methylphenol, with molecular formula $\mathrm{C}_{10} \mathrm{H}_{14} \mathrm{O}$ (Garcia-Risco et al. 2011; Walentowska and Foksowicz-Flaczyk 2012).

Moreover, FT/IR spectra showed the presence of phenol groups that have a strong antimicrobial activity against a wide range of microorganisms of fungi and bacteria either gram positive or gram negative (Sirvaityte et al. 2012; Soumya et al. 2011; Hu et al. 2008).

Current results indicated that the exposure of thymol to sun rays and UV lead to the yellowing of thymol, and IR spectra of exposed thymol samples indicated presence of $\mathrm{CH}$ aromatic, carbonyl and quinon groups. So, we could conclude that yellowing was attributed to the photochemical oxidation of phenol groups where thymoquinone or dithymoquinone have increased carbonyl absorption in the infrared spectrum (Sequeira et al. 2012; Daniels and Boyd 1986).

Moreover, the effect of thymol on the isolated fungi varied according to its concentration and fungal species since our results indicated that the concentration $10 \mu \mathrm{g} / \mathrm{ml}$ was not effective, but the concentration $100 \mu \mathrm{g} / \mathrm{ml}$ inhibited the growth of isolated fungi for ten days. Our finding agreed with those obtained by Haines and Kohler (1986) who tested effect of thymol against Aspergillus niger, Aureobasidiumpu pullulans, Cladosporium sp., Chaetomium sp., Fusarium sp., and Penicillium sp. colonizing archives and leather clothes and found that A. niger was the most resistant, but Fusarium sp. was the most sensitive to different thymol concentrations.

On the other hand, it has been established that thymol was effective against fungi colonizing a wide range of cultural heritage objects such as leather bindings and paper documents and A. niger, Emericella nidulans, A. solani, Penicillium rotatum, Fusarium oxysporum, Chaetomium globosum were the most present (Velikova et al., 2011).

From culture dependent and independent techniques, it was observed that microbiota are composed of different fungal species, and the isolated fungi varied in their resistance profile to tested thymol concentrations, since Penicillium sp. was the most resistant, but A. japonicus was the most sensitive at $100 \mu \mathrm{g}$. This an opinion also held by Wild (1954).

SEM micrographs indicated that treatment of A. japonicus, the most present fungus in the investigated tombs, with thymol $100 \mu \mathrm{g} / \mathrm{ml}$ delayed the fungal spore formation. This result explained the reason of mortality of treated fungi with thymol and was in agreement with the results obtained by Veilkova et al. (2011) showing that the treatment of A. niger with thymol caused deformation of fungal mycelium and significant changes of fungal spore were observed, also Bennis et al. (2004) reported TEM micrographs of Sacchromyces cervisiae treated with thymol showing significant deformation and apparent cracks in the treated yeast cells. Also, Walentowska and Foksowicz-Flaczyk (2012) found that thyme oil, the main source of thymol, completely inhibited the mycelial growth of Aspergillus flavus and exhibited a broad fungitoxic spectrum against Aspergillus niger, A. fumigatus and Alternaria alternata. 
Results derived from this study pointed out that thymol acted as fungistatic, where regrowth of treated fungi was observed after 10 days. This in agreement with Craig (1986), who inoculated filter paper samples with four cellulolytic fungi species, and treated with thymol by fumigation $\left(20 \mathrm{~g} / \mathrm{m}^{3}\right)$, with a constant temperature at $37^{\circ} \mathrm{C}$ for 3 days, and fungal growth appeared after 10 days of the treatment. On the other hand, the inhibitory effect of thymol on fungi was a temporarily effect and it was found that thymol $100 \mu \mathrm{g} / \mathrm{ml}$ delayed the fungal growth of Penicillium citrium for up to 9 days, but this fungus recolonized again (Vazuez et al. 2001). Furthermore, Gustafson et al. (1990) stated that thymol was not totally fungicidal for the fungal species tested, since the fungal spores were not totally eliminated, so it could be used in fumigation.

Our finding indicated that thymol in fumigation prevented recolonization of fungi for a long period of time, more than five months. These results are similar to those of Haines and Kohler (1986) where thymol was used for fumigation within fumigation chambers and could reduce the number of viable spores of fungi after the fumigation process was finished, because antifungal vapors had prolonging thymol effect on the treated fungi (Sequeira et al., 2012; Daniels and Boyd 1986).

Current results indicated that thymol vapors were effective decontaminating colonized objects of cultural heritage and this may be attributed to the continuous presence of thymol vapors within the exhibition cases that prevent growth of viable fungal spores (Rakotoniainy and Lavedrine 2005; Craig 1986), that allows a better penetration of the active compounds into the cultural heritage objects than liquids (Nugari 2003), and this efficacy of fumigation should be enhanced by low vapor pressure of thymol (Isabell, 1997).

Our finding indicated that amount of thymol required for fumigation ranged from $40-50 \mathrm{~g} / \mathrm{m}^{3}$, and the fumigation process lasted from 3 days to 12 days, this in agreement with Craig (1986) reported that weight of thymol required for fumigation ranged from 1 to $90 \mathrm{~g} / \mathrm{m}^{3}$, and the exposure time ranged from $24 \mathrm{~h}$ to 3 weeks.

On the other hand, it has been established that thymol fumigation could be used as a preventive conservation agent for sensitive organic materials stored in humid cases (Isbell, 1997).

Furthermore, FT/IR spectra indicated that thymol concentrations fumigated in this study had no effect on the investigated pigments such as hematite, limonite, malachite, azurite and black carbon. This agree with results obtained by Isabell (1997) who reported that thymol solution did not cause any changes to the treated pigments, but caused discoloration of inks in the treated manuscripts due to oxidation of phenol, and this phenomenon was well documented for organic pigments such as rose madder that was affected by exposure to thymol (Daniels and Boyd 1986).

\section{CONCLUSION}

Fungi involved significantly in biodeterioration of mural paintings within the tombs at Tell Basta by forming irreversible microbial stains and chromatic alterations by acids. Thymol was used in decontamination of fungi colonizing mural paintings and showed to be fungistatic since fungi recolonized after ten days of the treatment, so the fumigation method was used. The fungal resistance profile varied according to the fungal species, since A. japonicus was the most sensitive to thymol at $100 \mu \mathrm{g} / \mathrm{ml}$, (inhibition zone $25 \mathrm{~mm}$ ), but Penicillum sp. was the most resistant at the same concentration (inhibition zone $10 \mathrm{~mm}$ ). Using thymol at $40-50 \mathrm{~g} / \mathrm{m} 3$ for 3-12 days in the fumigation process reduced the numbers of fungi colonizing the tested objects of cultural heritage significantly. Thymol vapors were more effective in lower humidity than higher one. Finally, FT/IR spectra confirmed that thymol caused changes neither for the tested pigments nor for the surface appearance.

\section{ACKNOWLEDGMENTS}

Authors want to acknowledge Prof. Reda Fekry, Chemistry Department, Faculty of Science, Zagazig University for interpreting ${ }^{1} \mathrm{H}$ NMR spectra.

\section{REFERENCES}

Abdulla, H., Morshedy, H. and Derwed, A. (2008) Characterization of actinomycetes isolated from the indoor air of the church of Saint Katherine Monastery, Egypt. Aerobiologia, vol. 24, 35-41.

Abdel-Haliema, M.E.F., Ali, M. F., Ghaly, M. F., Sakra, A. A., (2013a) Efficiency of antibiotics and gamma irradiation in eliminating Streptomyces strains isolated from paintings of ancient Egyptian tombs, $J$. Cultural Heritage, vol.14, 45-50. 
Abdel-Haliem, M.E.F., Sakr, A.A., Ali, M.F., Ghaly, M.F., Sohlenkamp, C., (2013b) Characterization of Streptomyces isolates causing colour changes of mural paintings in ancient Egyptian tombs, Microbiological Research 168, 428-437.

Ahmad, A., Khan, S., Yousuf, S., Khan, S. Manzoor, N. (2010) Proton translocation ATPase mediated fungicidal activity of eugenol and thymol. Fitoterapia, vol. 81, 1157-1162.

Altiok D, Altiok E, Tihminlioglu F (2010) Physical, antibacterial and antioxidant properties of chitosan films incorporated with thyme oil for potential wound healing applications. J Mater Sci: Mater Med., vol. 21, 2227-2236.

Arai, H. (2004) Biological investigation, a report on the biological investigation in conservation of the wall paintings in the royal tomb of Amenophis III, First and second phases report, S. Yoshimura and J. Kondo (eds.), Institute of Egyptology, Waseda University.

Bennis, S., Chami, F., Chami, N., Bouchikhi, T. and Remmal, A. (2004) Surface alteration of Saccharomy cescervisiae induced by thymol and euganol. Letters in Applied Microbiology, vol. 38, 454-458.

Biswas, J., Sharma, K., Harris, KK. and Rajput, Y. (2013) Biodeterioration agents: Bacterial and fungal diversity dwelling in or on the pre-historic rock paints of Kabra-pahad, India. Iranian J. Microbiology, vol. 5, 309-3014.

Booth, C. (1977) Fusarium, laboratory guide to the identification, England, Cambridge University Press.

Caeser-Tonthat, T., Kloeke. FV., Geesey, GG. and Hensson, JM. (1995) Melanin production by a filamentous soil fungus in response to copper and localization of copper sulfide by sulfide -silver staining. Applied Environmental Microbiology, vol. 61, 1968-1975.

Collis, I.P., (1970) The use of thymol for document fumigation, J. Soc. Archivists, vol.4 (1), 53-54.

Craig, R. (1986) Alternative approaches to the treatment of mould biodeterioration an international problem. The Paper Conservator, vol. 10, 27-30.

Daniels, V. and Boyd, B. (1986) Yellowing of thymol in the display of prints. Studies in Conservation, vol. 31, 156-158.

da Silva, AC., Queiroz, AE., Porto, TS., Spier, MR., Soccol, CR., Porto, AL., Souza-Motta, CM. and Moreira, KA. (2012) Partial Characterization of an Inulinase produced by Aspergillus japonicus URM5633. Brazilian Archives of Biology and Tecacidhnology, vol. 55,671-676.

Derrick, MR., Stulik, D. and Landry, J. (1999) Infrared Spectroscopy in conservation science, Paul Getty Trust.

Descheemaeker, P. Swings, J. (1995) The application of fatty acid methyl ester analysis (FAME) for the identification of heterotrophic bacteria present in decaying Lede-stone of the St. Bavo in Ghent. The Science of the Total Environment, vol. 167, 241-247.

Domsch, K. H.; Gams, W. and Anderson, T. H. (1980) Compendium of soil fungi. Academic Press, London, pp 99.

El Deeb, A., El-Refaie, AA. and Melegy, M. (2000) Fungal contamination of the tomb of Petosiris and methods of treatment. Proceeding of the 8th International Congress of Egyptology 3: 166-170.

El Sharouny, M., Soltan, EM. and Mohamed, RM. (2000a) Aerospora of Abydos Temple at Upper Egypt. Egyptian J Microbiology, vol. 35, 391-408.

El Sharonuny, M., Soltan, EM. and Mohamed, RM. (2000b) Microflora inhabiting deteriorating wall paintings of Abydos Temple in Upper Egypt. Egyptian J Microbiology, vol. 36, 19-37.

Garg, KL., Jain, K. and Mishra, AK. (1995) Role of fungi in the bioderioration of wall paintings. The Science Total Environment, vol. 167, 255-271.

Garcia-Risco, MR., Vicente, G., Reglero, G. and Fornari, T. (2011) Fractionation of thyme (Thymus vulgaris L) by supercritical fluid extraction and chromatography. J Supercritical Fluids, vol. 55, 949-954.

Guglielminetti, M., De Giuli, M., Radaelli, A., Bistoni, F., Carruba, G., Spera, G. Caretta, G. (1994) Mycological and ultra-structural studies to evacuate biodeterioration of mural paintings. Detection of fungi and mites in frescoes of the monastery of St. Damian in Assisi. International Biodeterioration and Biodegradation, vol. 32, 269-283.

Gustafson, RA., Modaresi, I R., Hampton, GV., Chepesiuk, RJ. and Kelley, GA. (1990) Fungicidal efficacy of selected chemicals in thymol cabinets. J American Institute for Conservation, vol. 29, 153-168.

Haines, JH. and Kohler, SA.(1986) Evaluation of Ortho-Phenyl phenol as a fungicidal fumigant for archives and libraries. J American Institute for Conservation, vol. 25, 49-55.

Hu, Y., Du, Y., Wang, X. and Feng, T. (2008) Self aggregation of water-soluble chitosan and solubilization of thymolas antimicrobial agent. J Biomedical Materials Research Part A, 874-881.

Humar, M., Bokan, M., Amartey, SA., Sentjurc, M., Kalan, P. and Pohleven, F. (2004) Fungal bioremediation of copper,chromiumand boron treated wood as studied by electron paramagnetic resonance. International Biodeterioration and Biodegradation, vol. 53, 25-32. 
Isabell, LH. (1997) the effect of thymol on paper, pigments and media. Abbey Nwes letters, vol. 21, 39-43.

Kalinowski, BE., Liermann, LJ., Givens, S. Brantley, SL., (2000) Rates of Bacteria promoted solubilisation of Fe from minerals. Chemical Geology, vol. 169, 357-370.

Karbowska-Berent, J., Górny, RL., Strzelczyk, AB. and Wlazlo, A. (2011) Airborne and dust borne microorganisms in selected Polish libraries and archives. Building and Environment, vol. 46, 1872-1879

Kiyuna, T., Kigawa, KD., Sano, C., Miura, S. and Sugiyama, J. (2011) Molecular assessment of fungi in black spots that deface murals in the Takamatsuzuka and Kitora Tumuli in Japan: Acremonium sect. Gliomastix including Acremonium tumulicola sp. nov. and Acremonium felinum comb. nov. Mycoscience, vol. 52, 117.

Liang, H., Bao, F., Dong, X., Tan, R., Zang, C., Lu, Q. and Cheng, Y. ( 2007) Antibacterial thymol derivatives isolated from Centipeda minima. Molecules, vol. 12, 1606-1613.

Milanesi, C., Baldi, F., Vignani, R., Ciampolini, F., Faleri, C. and Cresti, M. (2006) Fungal deterioration of medieval wall fresco determined by analyzing small fragments containing copper. International Biodeterioration and Biodegradation, vol. 57, 7-13.

Nugari, MP. (2003) Biodeterioration control of cultural heritage: Methods and Problems, in Molecular Biology and Cultural Heritage, ed. C. Saiz-Jimenez, Balkama.

Numpaque, M.A., Oviedo, L.A., Gil, J. H., García, C.M., Durango, D.L., (2011) Thymol and carvacrol: biotransformation and antifungal activity against the plant pathogenic fungi Colletotrichum acutatum and Botryodiplodia theobromae, Tropical Plant Pathology, vol. 36, 1, 003-013.

Preusser, F. (1987) Scientific and technical examination of the tomb of Queen Nefertari at Thebes, in the conservation of wall paintings, Proceeding of a symposium, Institute of Paul Getty of Conservation, London, July 13-16, ed. S. Cather S.

Rakotonirainy, MS. and Lavedrine, B. (2005) Screening for antifungal activity of essential oils and related compounds to control the biocontamination in libraries and archives storage areas. International Biodeterioration and Biodegradation, vol. 55, 141-1471.

Raper, KB. and Fennell, D. (1977) The genus Aspergillus, Robert E. Krieger publishing Company, New York.

Raper, KB., Thom, C. and Fennell, D. (1968) A Manual of Penicilla, Hafner Publishing Company, New York.

Ravikumar, HR., Rao, SS. and Kraigar, CS. (2012) Biodeterioration of paints: a current status. Indian J. Science and Technology, vol. 5, 1977-1987.

Rota, MC., Herrera, A., Martinez, RM., Sotomayor, JA. and Jordan, MJ. (2008) Antimicrobial activity and chemical composition of Thymus vulgaris, Thymus zygis and Thymus hyemalis essential oils. Food Control, vol. 19:681-687.

Sadurska, I., and Kowalik, R., (1968) Fungi preventive for archival papers, Bullettino dell' Instituto di Patologia del Libero XXVII: I-II, $\quad 37-47$.

Sakr, AA., Ghaly, MF. and Abdel Haleim, ME. (2012) The efficacy of specific essential oils on yeast isolated from the royal tomb paintings at Tanis, Egypt. International J. Conservation Sciences, vol. 3, 87-92.

Sequeira, S., Cabrita, EJ. And Macedo, MF. (2012) Antifungals on paper conservation: An overview. International Biodeterioration and Biodegradation, vol.74, 67-86.

Šimonovicova, A., Godyova, M., and Ševc, J. (2004) Airborne and soil microfungi as contaminants of stone in a hypogean cemetery. International Biodeterioration and Biodegradation, vol. 54, 7-11.

Sirvaityte, J., Siugzadite, J., Valeika, V. and Dambrauskine, E. (2012) Application of essential oils of thym as natural preservative in leather tanning. Proceeding of the Estonian Academy of Sciences, vol. 61, $220-227$.

Soumya, E., Saad, I., Hassan, L., Ghizlane, Z., Hind, M. and Adnane, R. (2011) Carvacrol and thymol components inhibiting Pseudomonas aeruginosa adhering and biofilm formation. African J Microbiology Research, vol. 50: 3229-3232.

Sterflinger, K., Krumbein, WE. and Rullkotter, J. (1999) Patination of marble sandstone and granite by microbial communities. Zeitschrift der Deutschen Geologischen Gesellschaft, vol. 150, 299-311.

Sterflinger, K., (2010) Fungi: Their role in deterioration of cultural heritage, Fungal Biology Reviews, vol. 24, 47-55.

Strassberg, R. (1978) The use of fumigants in archival repositories. The American Archivist, vol. 41, 25-36.

Szezepanowska, H. and Lovett, C. (1992) Study on the removal and prevention fungal stains on paper. $J$ American Institute of Conservation, vol. 31, 147-160.

Unger, A., Schniewind, AP. and Unger, W. (2001) Conservation of wood artifacts, Springer-Verlag.

Vasanthakumar, A., De Araujo, A., Mazurek, J., Schilling, M. and Mitchell, R. (2013) Microbiological survey for analysis of the brown spots on the walls of the tomb of King Tutankhamun. International Biodeterioration and Biodegradation, vol. 79, 56-63. 
Vazuez, B., Fente, C., Franco, CM., Vazuez, MJ. and Cepeda, A. (2001) Inhibitory effects of euganol and thymol on Penicillium citrinum strains in culture media and cheese. International J Food Microbiology, vol. $67,157-163$.

Veilkova, T., Trepova, E. and Rozen, T. (2011) The use of biocides for the protection of library documents, before and after now, Science against microbial pathogen: communication current research and technological advances, ed. A. Mendezvilas, pp.152-159.

Walentowska, JJ. and Foksowicz-Flaczyk, F. (2012) Thyme essential oil for antimicrobial protection of natural textiles, International Biodeterioration and Biodegradation, (doi.org/10.1016/j.ibiod.2012.06.028), in press.

Wild, DG. (1954) The behaviourin presence of phynol and thymol of a stain Saccharomyces cerevisiae. Proceeding of the Royal Society of London, Series B, Biological Sciences, vol. 142, 427-436.

Citation: A. Sakr et al., "Effect of Thymol against Fungi Deteriorating Mural Paintings at Tell Basta Tombs, Lower Egypt", International Journal of Research Studies in Biosciences (IJRSB), vol. 6, no. 2, pp. 8-23, 2018. http://dx.doi.org/10.20431/2349-0365.0602003

Copyright: (c) 2018 Authors. This is an open-access article distributed under the terms of the Creative Commons Attribution License, which permits unrestricted use, distribution, and reproduction in any medium, provided the original author and source are credited. 